\title{
EVALUASI APLIKASI ASSET MANAGEMENT MENGGUNAKAN METODE RETURN ON INVESTMENT, INFORMATION ECONOMICS, DAN CRITICAL SUCCESS FACTOR DI UNIVERSITAS CONFIDENTIAL
}

\author{
Manatap Dolok Lauro \\ Program Studi Teknik Informatika Fakultas Teknologi Informasi Universitas Tarumanagara \\ Jalan Let. Jend. S. Parman No. 1, Jakarta 11440, Indonesia \\ Email:manataps@fti.untar.ac.id
}

\begin{abstract}
Abstrak
Investasi TI yang sudah selesai diimplementasi sebaiknya diikuti dengan proses evaluasi. Evaluasi akan memberikan gambaran apakah investasi TI tersebut sudah mencapai target yang ditentukan sebelumnya atau tidak, apakah investasi TI tersebut memberikan nilai guna ekonomis yang lebih baik daripada sebelum investasi tersebut dilakukan. Evaluasi yang dilakukan terhadap perangkat lunak Fixed Asset Management System di Universitas Confidential menggunakan metode Return On Investment, Information Economics, dan Critical Success Factor. Dengan adanya hasil evaluasi ini diharapkan pihak manajemen dapat mengetahui seberapa efektifnya investasi TI tersebut terhadap kinerja organisasinya.
\end{abstract}

Kata Kunci: Investasi TI, Metode Evaluasi ROI, IE, CSF.

\begin{abstract}
Implemented IT Investmest is best followed by IT evaluation process. IT Evaluation will determine whether IT investmenst has achieve investment target, whether the IT investment provide better economic value to organization before the IT investment was implemented. IT Evaluation conducted on Fixed Asset Management System in University Confidential is using Return On Investmenr method, Information Economics method, and Critical Success Factor method. By using the results of this evaluation, it is expected that management can know how effective is the IT investment to the performance of the organization.
\end{abstract}

Keywords: IT Investment, IT Evaluation Method: ROI, IE, CSF.

\section{PENDAHULUAN}

Dewasa ini penggunaan teknologi informasi semakin banyak dan memasuki area operasi dan strategis dari suatu organisasi. Adanya konsep Business Process Re-engineering (BPR) untuk semakin mengefisienkan suatu proses mendorong organisasi dalam mendapatkan keunggulan kompetitif dari para pesaingnya. Perbaikan proses bisnis ini dapat didukung dengan adanya teknologi informasi, yang bila dipadukan dengan tepat, dapat mempercepat laju proses bisnis, sebagai contoh, dapat dilihat dengan munculnya berbagai universitas yang sudah mulai menerapkan teknologi informasi dalam proses bisnisnya, salah satunya adalah Universitas Confidential yang berada di Jakarta, Indonesia. 
Sebuah masalah muncul di area fixed asset management akibat proses manual yang dilakukan oleh Universitas Confidential. Masalah muncul dikarenakan kurangnya kontrol terhadap aset-aset yang dimiliki. Universitas kemudian memutuskan untuk melengkapi Fixed Asset Management berbasis proses manual tersebut dengan sistem aplikasi program Fixed Asset Management dengan harapan dapat memperbaiki dan meningkatkan kinerja proses manajemen aset di universitas.

Yayasan kemudian menunjuk sebuah perusahaan IT Consultant untuk merancang sebuah aplikasi Fixed Asset Management System dimana aplikasi tersebut mencakup proses-proses utama dalam fixed asset management dari pendaftaran sampai pelepasan aset, dan berbagai tipe aset mulai dari peralatan kuliah sampai peralatan kantor. Pada bulan April 2009, aplikasi tersebut selesai dibangun dan sampai akhir tahun 2009, aplikasi tersebut sudah digunakan di seluruh bagian Universitas dan Yayasan.

Pada setiap investasi yang dikeluarkan untuk memperbaiki kinerja suatu proses di Universitas Confidential diharapkan memiliki suatu tujuan keberhasilan. Suatu penilaian atas keberhasilan aplikasi ini sangat diperlukan untuk menentukan apakah aplikasi tersebut dapat memberikan pertambahan nilai atau tidak, dan memberikan gambaran kepada tingkat manajerial untuk menentukan langkah-langkah strategis berikutnya agar Universitas Confidential tetap dapat memberikan kinerja yang semakin baik. Rencana strategis dari universitas berikutnya adalah mengembangkan aplikasi fixed asset management yang didasarkan atas kebutuhannnya akan kegiatan operasional sehari-hari dan kekurangan dari aplikasi sebelumnya dapat dihilangkan dengan meningkatkan value yang sebelumnya tidak ada dan mengurangi resikoresiko dari aplikasi sebelumnya yang didapat dari proses penilaian ini. Proses penilaian (evaluasi) ini adalah bagian dari siklus PDCA (Plan-Do-Check-Act), dimana tingkat manajerial melakukan perencanaan, impelementasi, evaluasi dan melakukan tindakan atas hasil evaluasi.

\section{PENELITIAN TERKAIT}

Investasi dalam bidang teknologi informasi biasanya termasuk dalam pengganggaran modal proyek utama, yang melibatkan dana yang banyak. Tetapi investasi teknologi informasi harus bersaing dengan project-project lain yang juga dapat menguntungkan perusahaan. Dalam beberapa kasus banyak perusahaan tidak dapat mengetahui apakah semua investasinya menguntungkan, dikarenakan modal perusahaan tidak cukup untuk melakukan semua investasi yang direncanakan[3].

Manfaat finansial dari sebuah sistem IT yang telah berjalan terkadang tidak dapat terlihat dengan jelas karena seringkali sistem IT lebih dekat ke proses operasi organisasi daripada sebagai suatu komoditi organisasi. Sangatlah sulit untuk menentukan apakah suatu sistem IT yang diterapkan dalam organisasi mendatangkan keuntungan bagi organisasi, ataukah mendatangkan pengeluaran baru yang tidak diharapkan. Oleh karena itu, metode evaluasi IT dibutuhkan untuk mengatasi masalah ini.Metode evaluasi yang digunakan adalah metode evaluasi yang dikhususkan untuk mengevaluasi sistem informasi. Metode evaluasi sistem informasi yang digunakan juga beragam, yang bertujuan untuk dapat melihat hasil efisiensi dan efektivitas aplikasi dari berbagai sudut pandang, yaitu dari sudut pandang finansial, dan nonfinansial seperti kuantitatif dan kualitatif.

Metode evaluasi di bidang TI bermula dari berkembangnya teknologi informasi di dunia. Metode-metode saat itu dirancang untuk memberi penilaian kepada proyek-proyek TI yang berjalan, apakah sudah memenuhi tujuan perancangan atau belum. Seiring dengan waktu, metode-metode evaluasi tersebut berkembang dan sampai saat ini terdapat banyak sekali metode 
evaluasi yang digunakan. Menurut [1], terdapat 82 metode yang memiliki obyek evaluasi yang berbedabeda.

Besarnya jumlah metode evaluasi tersebut mendorong praktisi TI mengkategorikannya dalam sudut pandang yang sesuai dengan lingkup bahasannya, salah satu contoh pengkategorian yang digunakan dalam evaluasi ini adalah sebagai berikut: [1]

1. Metode evaluasi TI berdasarkan sudut pandang finansial Metode evaluasi ini memiliki hasil akhir berupa informasi finansial atau suatu kesimpulan yang memiliki arti finansial. Metode ini menggunakan nilai investasi TI dengan menganalisa aliran cash-in, aliran cashout, dan berbagai perwakilan nilai finansial untuk sesuatu yang tidak bisa diukur nilai ekonomisnya. Metode-metode yang termasuk di dalam metode evaluasi finansial antara lain: Return On Investment (ROI), Accounting Rate of Return (ARR), Breakeven Analysis, Cost Benefit Analysis (CBA), Internal Rate of Return (IRR), Net Present Value (NPV), Payback Period, Time Savings Times Salary, Return On Management (ROM).

2. Metode evaluasi TI berdasarkan sudut pandang kuatitatif Metode evaluasi ini memiliki hasil akhir berupa beberapa hasil perhitungan non-finansial dan hasil pengukuran kutitatif untuk setiap investasi TI yang dievaluasi. Metode ini tidak hanya menggunakan kriteria finansial dalam melakukan pengukuran, tetapi juga menggunakan kriteria non-finansial. Setiap kriteria yang disebutkan dalam evaluasi, memiliki satu hasil pengukuran. Metodemetode yang termasuk di dalam metode evaluasi kuantitatif antara lain: Information Economics (IE), Application Benchmark Technique, Balanced Scorecard, Bayesian Analysis, Information Systems Investment Strategies (ISIS), Option Theory, Seven Milestone Approach, Value Analysis (VA).

3. Metode evaluasi TI berdasarkan sudut pandang kualitatif Metode evaluasi ini memberikan hasil akhir berupa diagram portfolio dan pernyataan secara subyektif yang tidak bersifat kuantitatif. Hasil akhir dapat saja tidak berupa informasi finansial, tetapi tidak tertutup kemungkinan hasil akhir tersebut berupa pendapat finansial. Metode-metode yang termasuk di dalam metode evaluasi kualitatif antara lain: Critical Success Factors (CSF), Investment Mapping, Investment Portfolio, Potential Problem Analysis (PPA), Prototyping, Strategic Option Generator, Value Chain Assessment, User Attitudes.

Untuk menghitung simple Return of Investment, menggunakan tiga lembar kerja, yaitu: [2]

1. Lembar kerja biaya pengembangan (development cost worksheet),

2. Lembar kerja biaya berjalan (ongoing expenses worksheet), dan

3. Lembar kerja dampak ekonomi (economic impact worksheet).

Information Economics (IE) adalah suatu sekumpulan metode untuk menghitung cost dan benefit dari sebuah proyek teknologi informasi beserta dengan dampak terhadap tujuan strategis perusahaan, dan dampak terhadap infrastrtuktur teknologi perusahaan [2]. Menurut [2], "Value dibuat berdasarkan keunggulan yang dicapai dari kompetisi, direfleksikan dari performa bisnis saat kini dan saat mendatang. Oleh karena itu, manajemen akan memilih untuk berinvestasi untuk meningkatkan value dalam organisasi sehingga akan mendapatkan keunggulan kompetitif".

IE adalah suatu metode evaluasi yang dilihat dari sudut pandang kuantitatif [1]. Metode IE menggunakan cost dan value, tools dan pengukuran dalam melakukan evaluasi investasi TI. Metode ini juga memperhitungkan evaluasi resiko dalam pengambilan keputusan. Metode IE terdiri dari 3 bagian, yaitu economic domain (enhanced ROI), business domain, dan technology domain. Bagan berikut adalah pembagian dari antara ketiganya: [1] 


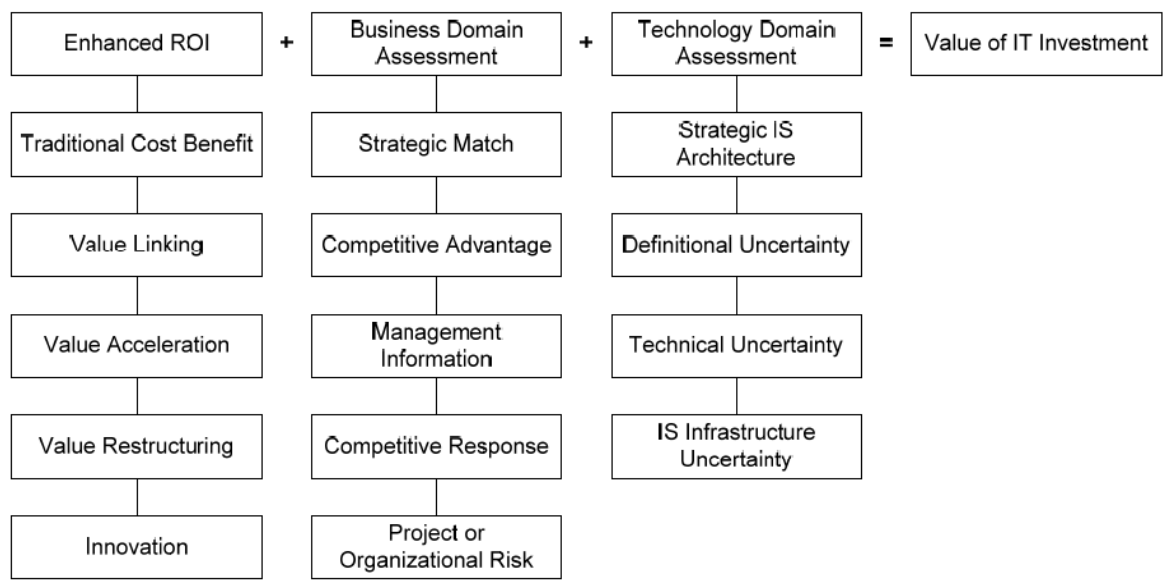

Gambar 1. Rumus Perhitungan Information Economics

Critical Success Factor (CSF) adalah suatu suatu batas kritis atau aktivitas yang harus dipenuhi oleh suatu organisasi atau proyek untuk mencapai kesuksesan bisnisnya[4]. Konsep CSF dikembangkan pertama kali oleh D. Ronald Daniel (McKinsey \& Company) pada tahun 1961. Kemudian disempurnakan oleh Jack F. Rockart pada tahun 1986. Rockhart mendefinisikan CSF sebagai "Sejumlah area terbatas, yang mana bila terpenuhi, sebuah organisasi dapat sukses berkompetisi.", "Area aktivitas dimana pihak manajemen harus selalu memberi perhatian secara konstan dan menyeluruh.”[4].

CSF berhubungan sangat erat dengan misi dan tujuan strategi bisnis. Misi dan tujuan strategi bisnis berfokus pada tujuan dan apa yang harus dicapai, sedangkan CSF berfokus pada area yang sangat penting, yaitu apa yang harus dicapai organisasi dan bagaimana cara mencapainya [1].

\section{METODE PENELITIAN}

Evaluasi TI dengan metode Return Of Investment menggunakan beberapa data finansial yang memiliki hubungan dengan proses Asset Management yang terjadi. Data yang diambil merupakan data yang langsung berasal dari universitas (data primer) dan merupakan data terbaru yang sejalan dengan rentang waktu implementasi aplikasi Fixed Asset Management System.

Metode evaluasi yang termasuk dalam metode kuantitatif adalah metode yang memberikan hasil yang bukan berupa informasi finansial dan yang merupakan pengukuran kuantitatif dari investasi sistem informasi. Metode kuantitatif yang digunakan dalam evaluasi ini adalah Information Economics (IE). Metode IE dipilih karena IE menggunakan cost dan value, tools, dan pengukuran untuk sistem informasi. Selain itu, IE mengevaluasi resiko sistem informasi, sehingga hasil analisis yang diberikan lebih detail dan luas. Secara umum, IE memiliki 3 bahasan, yaitu economic domain, business domain dan technology domain. Dalam kaitannya dengan evaluasi sistem informasi Fixed Asset Management System di Universitas Confidential, ketiga faktor ini dibahas dan dihitung.

Dalam melakukan evaluasi TI dengan menggunakan metode CSF, diperlukan pengambilan data berupa wawancara dengan stakeholder obyek evaluasi, yang kemudian dilanjutkan dengan beberapa tahapan berikut: 
1. Interview dengan stakeholder. Tahap awal melakukan interview dengan para stakeholder dengan topik Critical Success Factor apa yang mereka anggap ada di organisasi.

2. Mendaftar CSF. Dari seluruh CSF yang didapat saat interview dengan para stakeholder kemudian dikompilasi dan dipadatkan sehingga tidak ada CSF yang memiliki arti yang sama atau mendekati sama.

3. Mengurutkan daftar CSF. Tahapan terakhir adalah mengurutkan CSF berdasarkan faktor yang terpenting lebih dahulu.

\section{HASIL DAN PEMBAHASAN}

Hasil analisis Return On Investment melibatkan metode Simple ROI dimana perhitungan Simple ROI terdiri dari perhitungan biaya pembangunan sistem (Development Cost), biaya berjalan (Ongoing Expense). Masing-masing dari biaya ini dimasukkan ke dalam Economic Impact Worksheet.

Pengambilan data untuk perhitungan Simple ROI menggunakan metode wawancara dengan pihak Internal Auditor universitas. Perbincangan dengan pihak Internal Auditor universitas akan membicarakan seputar proses bisnis Asset Management yang selama ini terjadi. Proses bisnis tersebut kemudian dibandingkan antara keadaan sebelum implementasi sistem dengan keadaan setelah implementasi. Hasil analisis kedua kondisi ini kemudian diterjemahkan kedalam perhitungan dan tabel-tabel sehingga membentuk Simple ROI.

Tabel 1.Development Cost Worksheet

\begin{tabular}{|l|r|}
\hline A. Biaya pembangunan sistem & \\
\hline 1. Jasa konsultan & $\mathrm{Rp} \mathrm{240,000,000}$ \\
\hline & \\
\hline B. Biaya pembelian perangkat keras & \\
\hline 1. Application Server & $\mathrm{Rp} \mathrm{26,000,000}$ \\
\hline 2. Barcode Printer & $\mathrm{Rp} 12,000,000$ \\
\hline 3. Barcode Scanner & $\mathrm{Rp} 15,000,000$ \\
\hline & \\
\hline C. Biaya pembelian perangkat lunak & \\
\hline 1. Microsoft Windows Server & $\mathrm{Rp} \mathrm{3,000,000}$ \\
\hline 2. Microsoft SQL Server & $\mathrm{Rp} 8,000,000$ \\
\hline & \\
\hline TOTAL & $\mathrm{Rp} 304,000,000$ \\
\hline
\end{tabular}

Berikut adalah penjabaran komponen-komponen pembentuk biaya berjalan aplikasi Fixed Asset Management System:

1. Biaya jasa maintenance aplikasi sebesar Rp. 20.000 .000 per tahun. Jasa maintenance dilakukan oleh perusahaan konsultan pembangun aplikasi Fixed Asset Management System sebelumnya. Maintenance terhadap aplikasi dilakukan untuk menjaga keadaan data tetap teroganisasi dengan baik. Diperkirakan bahwa biaya ini akan naik $10 \%$ tiap tahunnya.

2. Biaya supply barcode printer yang berupa Kertas untuk barcode dan Pita. Khusus untuk tahun pertama, yaitu saat dimana seluruh invetori universitas dimasukkan ke dalam sistem, membutuhkan 10 rol Sticker barcode dan 7 rol Pita printer. Keseluruhan supply ini berjumlah sebesar Rp. 4.175.000. Diperkirakan bahwa biaya ini akan naik 10\% tiap tahunnya. 
3. Biaya supply barcode printer untuk tahun berikutnya diperkirakan hanya menggunakan 1 pasang rol Sticker dan 1 rol pita. Sehingga biaya per-tahun $=$ Rp. 187.500. Diperkirakan bahwa biaya ini akan naik $10 \%$ tiap tahunnya.

Tabel 2.Ongoing Cost Worksheet

\begin{tabular}{|l|r|r|r|}
\hline & $\mathbf{2 0 0 9}$ & $\mathbf{2 0 1 0}$ & $\mathbf{2 0 1 1}$ \\
\hline Maintenance & - & $20,000,000$ & $22,000,000$ \\
\hline Kertas, Pita & $4,275,000$ & 187,500 & 206,250 \\
\hline TOTAL & $4,275,000$ & $20,187,500$ & $22,206,250$ \\
\hline
\end{tabular}

Aplikasi Fixed Asset Management System dirancang untuk mempermudah proses manajemen aset di universitas. Beberapa pekerjaan yang sebelumnya dilakukan secara manual, maka saat ini pihak fakultas dapat menggunakan aplikasi ini yang mempunyai data yang tersentralisasi.

Dengan aplikasi Fixed Asset Management System, setiap fakultas dapat melakukan perubahan informasi lokasi setiap kali inventori yang mereka miliki dipindahkan atau hilang. Sehingga data yang mereka miliki selalu data yang terbaru. Pekerjaan yang dilakukan setiap akhir semester dapat mereka hindari. Sehingga penghematan yang mereka dapatkan per tahun adalah $=2$ orang per fakultas $\mathrm{x} 14$ fakultas $\mathrm{x} 2$ semester per tahun $\mathrm{x}$ (gaji Rp. $1.800 .000 / 20$ hari $\mathrm{x} 10$ hari $)=$ Rp. 50.400.000. Diasumsikan gaji naik 10\% setiap tahunnya.

Value Linking digunakan untuk mengkategorikan berbagai keunggulan finansial yang didapat setelah implementasi aplikasi Fixed Asset Management System. Value Acceleration digunakan untuk mengkategorikan keunggulan finansial karena adanya pengurangan waktu proses yang dapat dicapai akibat menggunakan aplikasi ini. Kedua faktor ini disatukan dalam Net Economic Benefit.

Waktu pembuatan report untuk pihak manajemen dapat dipersingkat menjadi hitungan detik. Sebelumnya, pihak manajemen setiap fakultas memerlukan laporan inventori setiap semester. Laporan ini juga disampaikan ke pihak manajemen yayasan sebagai salah satu bentuk pertanggungjawaban setiap kepala fakultas. Sebelum implementasi sistem, setiap perancangan report membutuhkan waktu 3 hari. Waktu tersebut digunakan untuk membuat daftar inventori berdasarkan daftar lama dan menambahkan inventori jika selama 1 semester terbuat terdapat penambahan inventori. Apabila keseluruhan fakultas yang berjumlah 8 fakultas membuat laporan setiap akhir semester maka jumlah biaya yang dapat dihindari setiap tahun adalah $=14$ Fakultas x (Gaji Rp 1.800.000 / 20 hari x 3 hari) x 2 kali setahun = Rp. 7.560.000.

Hasil evaluasi berdasarkan ROI yang dapat digunakan untuk melakukan enhancement berikutnya dititik-beratkan pada peningkatan benefit yang dihasilkan oleh aplikasi, berikut adalah rinciannya:

1. Melihat dari nilai ROI yang ada, rencana enhancement Aplikasi Fixed Asset Management System dapat difokuskan untuk mengeliminasi pekerjaan yang dilakukan oleh karyawan, tentunya dengan menitikberatkan pada peningkatan Dampak Ekonomi Langsung.

2. Aplikasi enhancement harus dapat memberikan dampak Value Linking yang secara jelas meningkatkan nilai ROI. Aplikasi harus dapat berkomunikasi langsung dengan aplikasi lain, misalnya aplikasi Accounting, aplikasi Perencanaan Ruang Kelas dan Penjadwalan agar proses komputerisasi yang terjadi di universitas tidak terjadi berulang-ulang. 
Computatio: Journal of Computer Science and Information Systems, volume 1, no 2, Oktober 2017

Metode analisis Information Economics untuk investasi Universitas Confidential pada bidang Asset Management dengan mengimplementasi aplikasi Fixed Asset Management System dimulai dari perhitungan Enhanced ROI, yaitu yang terdiri dari perhitungan Traditional Cost \& Benefit, Value Linking, Value Acceleration, Value Restructuring, dan Innovation. Pengambilan data untuk perhitungan Enhanced ROI menggunakan metode wawancara dengan pihak Internal Auditor universitas. Perbincangan dengan pihak Internal Auditor universitas akan membicarakan seputar proses bisnis Asset Management yang selama ini terjadi. Proses bisnis tersebut kemudian dibandingkan antara keadaan sebelum implementasi sistem dengan keadaan setelah implementasi. Hasil analisis kedua kondisi ini kemudian diterjemahkan kedalam perhitungan dan tabel-tabel sehinggan membentuk Enhanced ROI.

Tabel 3.Enhanced Return On InvestmentScore Table

A. Net Investment

$304,000,000$

B. Yearly Cashflow

Net Economic Benefit

$$
\text { yr } 2009
$$$$
\text { yr } 2010
$$

yr 2011

Operating Cost Reduction

$7,560,000$

$8,316,000$

$9,147,600$

Ongoing Expense

$$
50,400,000
$$

$55,440,000$

$60,984,000$

Net Cashflow

$-4,275,000$

$-20,187,000$

$-22,206,250$

$46,125,000$

$35,253,000$

$38,777,750$

Total

$265,335,100$

C. Simple ROI $(B /$ years / $A)$

0.29093761

Percentage

$29.09 \%$

D. Scoring

\begin{tabular}{|c|c|}
\hline ROI Score & Simple ROI \\
\hline 0 & $<1 \%$ \\
\hline 1 & $1 \%-299 \%$ \\
\hline 2 & $300 \%-499 \%$ \\
\hline 3 & $500 \%-699 \%$ \\
\hline 4 & $700 \%-899 \%$ \\
\hline 5 & Over $899 \%$ \\
\hline
\end{tabular}


Tabel 4.Rincian Information Economics Scoring

\begin{tabular}{|c|c|c|}
\hline \multicolumn{3}{|c|}{ BUSINESS DOMAIN } \\
\hline SCORE & \multicolumn{2}{|c|}{ SUB DOMAIN } \\
\hline 1 & \multicolumn{2}{|c|}{ RETURN ON INVESTMENT - ROI } \\
\hline & 0 & $<1 \%$ \\
\hline & 1 & $1 \%-299 \%$ \\
\hline & 2 & $300 \%-499 \%$ \\
\hline & 3 & $500 \%-699 \%$ \\
\hline & 4 & $700 \%-899 \%$ \\
\hline & 5 & lebih dari $899 \%$ \\
\hline 1 & \multicolumn{2}{|c|}{ STRATEGIC MATCH - SM } \\
\hline & 0 & $\begin{array}{l}\text { Project tidak memiliki hubungan langsung maupun tidak langsung terhadap } \\
\text { pencapaian tujuan strategis perusahaan }\end{array}$ \\
\hline & 1 & $\begin{array}{l}\text { Project tidak memiliki hubungan langsung maupun tidak langsung terhadap } \\
\text { pencapaian tujuan strategis perusahaan, tetapi akan mencapai efisiensi } \\
\text { operasional yang lebih baik }\end{array}$ \\
\hline & 2 & $\begin{array}{l}\text { Project tidak memiliki hubungan langsung terhadap pencapaian tujuan } \\
\text { strategis perusahaan, tetapi merupakan prasyarat terhadap sistem lain yang } \\
\text { mencapai sebagian tujuan strategis tersebut }\end{array}$ \\
\hline & 3 & $\begin{array}{l}\text { Project tidak memiliki hubungan langsung terhadap pencapaian tujuan } \\
\text { strategis perusahaan, tetapi merupakan prasyarat terhadap sistem lain yang } \\
\text { mencapai tujuan strategis tersebut }\end{array}$ \\
\hline & 4 & $\begin{array}{l}\text { Project langsung mencapai sebagian dari tujuan strategis perusahaan yang } \\
\text { telah ditetapkan }\end{array}$ \\
\hline & 5 & Project langsung mencapai tujuan strategis perusahaan yang telah ditetapkan \\
\hline \multirow[t]{7}{*}{0} & \multicolumn{2}{|c|}{ COMPETITIVE ADVANTAGE - CA } \\
\hline & 0 & $\begin{array}{l}\text { Project tidak menciptakan akses atau pertukaran data antara perusahaan } \\
\text { dengan unit kerjasama di luar }\end{array}$ \\
\hline & 1 & $\begin{array}{l}\text { Project tidak menciptakan akses atau pertukaran data seperti diatas, tetapi } \\
\text { meningkatkan posisi kompetitif perusahaan dengan meningkatkan efisiensi } \\
\text { operasinya yang menunjang kinerja kompetitif perusahaan }\end{array}$ \\
\hline & 2 & $\begin{array}{l}\text { Project tidak menciptakan akses atau pertukaran data seperti diatas, tetapi } \\
\text { meningkatkan posisi kompetitif perusahaan dengan meningkatkan efisiensi } \\
\text { operasinya pada suatu area strategis kunci }\end{array}$ \\
\hline & 3 & $\begin{array}{l}\text { Project menyediakan akses keluar atau pertukaran sedikit data dan } \\
\text { meningkatkan posisi kompetitif perusahaan }\end{array}$ \\
\hline & 4 & $\begin{array}{l}\text { Project menyediakan akses keluar atau pertukaran cukup banyak data dan } \\
\text { secara substansial meningkatkan posisi kompetitif perusahaan dengan } \\
\text { menyediakan tingkat pelayanan yang lebih baik daripada para pesaing }\end{array}$ \\
\hline & 5 & $\begin{array}{l}\text { Project menyediakan akses keluar atau pertukaran banyak data dan sangat } \\
\text { meningkatkan posisi kompetitif perusahaan dengan menyediakan tingkat } \\
\text { pelayanan yang tidak dimiliki pesaing }\end{array}$ \\
\hline
\end{tabular}


Computatio: Journal of Computer Science and Information Systems, volume 1, no 2, Oktober 2017

\begin{tabular}{|c|c|c|}
\hline \multirow[t]{7}{*}{5} & \multicolumn{2}{|c|}{ MANAGEMENT INFORMATION - MI } \\
\hline & 0 & $\begin{array}{l}\text { Project tidak berkaitan dengan dukungan informasi manajemen kegiatan } \\
\text { kunci (management information support of core activities, MISCA) } \\
\text { perusahaan }\end{array}$ \\
\hline & 1 & $\begin{array}{l}\text { Project tidak berkaitan dendan MISCA, tetapi menyediakan banyak data } \\
\text { pada fungsi yang mendukung langsung kegiatan kunci perusahaan }\end{array}$ \\
\hline & 2 & $\begin{array}{l}\text { Project tidak berkaitan dendan MISCA, tetapi menyediakan banyak } \\
\text { informasi pada fungsi yang mendukung langsung kegiatan kunci perusahaan }\end{array}$ \\
\hline & 3 & $\begin{array}{l}\text { Project tidak berkaitan dendan MISCA, tetapi menyediakan banyak } \\
\text { informasi penting pada fungsi yang diidentifikasikan sebagai kegiatan kunci } \\
\text { perusahaan. Informasi ini bersifat operasional }\end{array}$ \\
\hline & 4 & Project penting untuk membuat MISCA di masa yang akan datang \\
\hline & 5 & Project penting untuk membuat MISCA di masa sekarang \\
\hline \multirow[t]{7}{*}{4} & \multicolumn{2}{|r|}{ COMPETITIVE RESPONSE - CR } \\
\hline & 0 & $\begin{array}{l}\text { Project dapat diunda hingga } 12 \text { bulan mendatang tanpa mempengaruhi } \\
\text { posisi kompetitif, atau sistem dan prosedur yang ada secara substansial } \\
\text { dapat memberikan hasil yang sama dan tidak akan mempengaruhi posisi } \\
\text { kompetitif }\end{array}$ \\
\hline & 1 & $\begin{array}{l}\text { Penundaan project tidak mempengaruhi posisi kompetitif perusahaan, dan } \\
\text { biaya tenaga kerja yang rendah diharapkan tetap dapat memberikan hasil } \\
\text { yang sama }\end{array}$ \\
\hline & 2 & $\begin{array}{l}\text { Penundaan project tidak mempengaruhi posisi kompetitif perusahaan, tetapi } \\
\text { upah tenaga kerja dapar meningkat guna mendapatkan hasil yang sama }\end{array}$ \\
\hline & 3 & $\begin{array}{l}\text { Jika project ditnda, perusahaan tetap mampu memberikan respon terhadap } \\
\text { perubahan yang diperlukan tanpa mempengaruhi posisi kompetitif, } \\
\text { kekurangan pada sistem baru, tidak menghalangi kemampuan respon } \\
\text { perusahaan terhadap keefektifan perubahan dalam lingkungan kompetitif }\end{array}$ \\
\hline & 4 & $\begin{array}{l}\text { Penundaan project mungkin mengakibatkan tingkat kompetisi yang lemah } \\
\text { terhadap perusahaan, atau kehilangan kesempatan kompetitif, atau } \\
\text { keberhasilan kegiatan yang ada pada perusahaan mungkin terbatas karena } \\
\text { tiadanya sistem yang diusulkan }\end{array}$ \\
\hline & 5 & $\begin{array}{l}\text { Penundaan project ini mengakibatkan kerugian kompetitif masa datang, atau } \\
\text { kehilangan peluang kompetitif, atau keberhasilan kegiatan yang ada pada } \\
\text { project menjadi terbatas karena tiadanya sistem yang diusulkan }\end{array}$ \\
\hline 0.5 & \multicolumn{2}{|c|}{ ORGANISATIONAL RISK - OR } \\
\hline & 0 & $\begin{array}{l}\text { Perusahaan memiliki rencana yang terformuliasi dengan baik untuk } \\
\text { mengimplemantasikan sistem yang diusulkan. Manajemennya memadai, } \\
\text { proses dan prosedur ada terdokumentasi. Terdapatnya contigency plan untuk } \\
\text { proyek, adanya unggulan project, serta nilai tambah produk atau nilai } \\
\text { tambah kompetitid terdefinisi dengan jelas untuk pasar yang telah diketahui } \\
\text { dengan baik. }\end{array}$ \\
\hline
\end{tabular}




\begin{tabular}{|c|c|c|}
\hline & $1-4$ & rencana business domain yang terformulasi dengan baik \\
\hline & & manajemen business domian pada tempatnya \\
\hline & & contigency plan pada tempatnya \\
\hline & & proses dan prosedur pada tempatnya \\
\hline & & pelatihan bagi para pengguna terencana \\
\hline & & adanya manajemen unggulan \\
\hline & & produknya ditentukan dengan baik \\
\hline & & kebutuhan pasar dipahami dengan jelas \\
\hline & 5 & $\begin{array}{l}\text { Perusahaan tidak memiliki rencana yang terformulasi dengan baik untuk } \\
\text { mengimplementasikan sistem yang diusulkan. Manajemen tidak mempunyai } \\
\text { kepastian mengenai tanggung jawab. Proses dan prosedur tidak } \\
\text { terdokumentasi. Tidaka ada contigency plan. Tidak ada unggulan yang } \\
\text { ditentukan sebagai inisiatif. Nilai tambah produk atau kompetitif tidak } \\
\text { didefinisikan dengan baik. Tiada ada pasar yang dipahami dengan baik. }\end{array}$ \\
\hline \multicolumn{3}{|c|}{ TECHNOLOGY DOMAIN } \\
\hline SCORE & \multicolumn{2}{|c|}{ SUB DOMAIN } \\
\hline 2 & \multicolumn{2}{|c|}{ IS INFRASTRUCTURE - SA } \\
\hline & 0 & Project yang dibangun tidak sesuai dengan yang direncanakan \\
\hline & 1 & $\begin{array}{l}\text { Project yang dibangun adalah bagian dari yang direncanakan, tetapi } \\
\text { prioritasnya tidak ditentukan }\end{array}$ \\
\hline & 2 & $\begin{array}{l}\text { Project yang dibangun adalah bagian dari yang direncanakan, dan hasilnya } \\
\text { rendah, bukan merupakan prasyarat bagi blueprint project lain, juga tidak } \\
\text { terkait erat dengan prasyarat project lainnya }\end{array}$ \\
\hline & 3 & $\begin{array}{l}\text { Project yang dibangun merupakan bagian integral dari blueprint dan } \\
\text { memiliki hasil yang tinggi, bukan merupakan prasyarat bagi blueprint } \\
\text { project lain, tetapi agak terkait dengan prasyarat porject lain }\end{array}$ \\
\hline & 4 & $\begin{array}{l}\text { Project yang dibangun merupakan bagian integral dari blueprint dan } \\
\text { memiliki hasil yang tinggi, bukan merupakan prasyarat bagi blueprint } \\
\text { project lain, tetapi sangat terkait dengan prasyarat porject lain }\end{array}$ \\
\hline & 5 & $\begin{array}{l}\text { Project yang dibangun merupakan bagian integral dari blueprint dan akan } \\
\text { diimplementasikan lebih dahulu, project merupakan prasyarat bagi blueprint } \\
\text { project lain }\end{array}$ \\
\hline \multirow[t]{5}{*}{1} & \multicolumn{2}{|c|}{ DEFINITIONAL UNCERTAINTY - DU } \\
\hline & 0 & $\begin{array}{l}\text { Syarat-syarat dan spesifikasinya jelas dan disetujui. Area yang ditelaah } \\
\text { jelas. Memiliki probabilitas tidak adanya perubahan yang tinggi }\end{array}$ \\
\hline & 1 & $\begin{array}{l}\text { Syarat-syarat dan spesifikasinya cukup jelas. Tidak ada persetujuan resmi. } \\
\text { Area yang ditelaah jelas. Memiliki probabilitas perubahaan non rutin yang } \\
\text { rendah }\end{array}$ \\
\hline & 2 & $\begin{array}{l}\text { Syarat-syarat dan spesifikasinya cukup jelas. Area yang ditelaah jelas. } \\
\text { Memiliki probabilitas perubahaan non rutin yang normal }\end{array}$ \\
\hline & 3 & $\begin{array}{l}\text { Syarat-syarat dan spesifikasinya cukup jelas. Tidak ada persetujuan resmi. } \\
\text { Area yang ditelaah jelas. Memiliki probabilitas perubahaan non rutin } \\
\text { hampir pasti hampir mendadak }\end{array}$ \\
\hline
\end{tabular}




\begin{tabular}{|c|c|c|}
\hline & 4 & $\begin{array}{l}\text { Syarat-syarat dan spesifikasinya tidak jelas. Area yang ditelaah cukup } \\
\text { kompleks. Perubahan-perubahan mendekati pasti, bahkan selama periode } \\
\text { project }\end{array}$ \\
\hline & 5 & $\begin{array}{l}\text { Syarat-syarat dan spesifikasinya tidak diketahui. Area yang ditelaah } \\
\text { mungkin cukup kompleks. Perubahan mungkin terjaid selama proses } \\
\text { berjalan, tetapi intinya adalah syarat-syarat yang tidak diketahui }\end{array}$ \\
\hline 2 & \multicolumn{2}{|c|}{ IS INFRASTRUCTURE RISK - IR } \\
\hline & 0 & $\begin{array}{l}\text { Sistem ini memakai fasilitas dan layanan yang ada. Tidak ada investasi } \\
\text { menyangkut fasilitas prasyarat sistem informasi yang diperlukan (misal } \\
\text { manajemen database), tidak ada biaya awal yang bukan merupakan bagian } \\
\text { project yang secara langsung diantisipasi. }\end{array}$ \\
\hline & 1 & $\begin{array}{l}\text { Perubahan terhadap sebuah elemen dari sistem pengiriman layanan } \\
\text { komputer dibutuhkan bagi project ini. Investasi awal terkait di luar dari } \\
\text { biaya langsung project relatif kecil. }\end{array}$ \\
\hline & 2 & $\begin{array}{l}\text { Dibutuhkan sedikit perubahan pada beberapa elemen sistem pengiriman } \\
\text { layanan komputer. Beberapa investasi awal dibutuhkan untuk } \\
\text { mengakomodasi project ini, investasi berikutnya untuk integrasi lebih lanjut } \\
\text { project ini ke dalam ligkungan alur utama sistem informasi mungkin } \\
\text { dibutuhkan }\end{array}$ \\
\hline & 3 & $\begin{array}{l}\text { Dibutuhkan perubahan yang cuku tehradap beberapa elemen sistem } \\
\text { pengiriman layanan komputer. Dibuthkan investasi cukup besar pada awal } \\
\text { project untuk mengakomodasi project ini, dibuthkan juga cukup banyak } \\
\text { investasi berikutnya untuk integrasi lebih lanjut project ini dengan } \\
\text { lingkungan alur utama sistem informasi }\end{array}$ \\
\hline & 4 & $\begin{array}{l}\text { Pada beberapa area, dibuthkan perubahan yang cukup terhadap beberapa } \\
\text { elemen sistem pengiriman layanan komputer. Dibuthkan investasi cukup } \\
\text { besar pada awal project untuk staf, perangkat lunak, perangkat keras, dan } \\
\text { manajemen untuk mengakomodasi project ini. Investasi ini tidak termasuk } \\
\text { dalam biaya project secara langsung, tetapi mewakili investasi fasilitas } \\
\text { sistem informasi untuk menciptakan lingkungan yang dibutuhkan pada } \\
\text { project ini }\end{array}$ \\
\hline & 5 & $\begin{array}{l}\text { Dibutuhkan perubahan substansial pada beberapa elemen sistem pengiriman } \\
\text { layanan komputer di beberapa area. Investasi awal yang dapar } \\
\text { dipertimbangkan dalam staf, perangkat lunak, perangkat keras, dan } \\
\text { manajemen dibutuhkan untuk mengakomodasi project ini. Investasi ini } \\
\text { tidak termasuk dalam biaya project secara langsung, tetapi mewakili } \\
\text { investasi fasilitas sistem informasi untuk menciptakan lingkungan yang } \\
\text { dibutuhkan pada project ini }\end{array}$ \\
\hline & \multicolumn{2}{|c|}{ TECHNICAL UNCERTAINTY - TU } \\
\hline \multirow[t]{3}{*}{2} & A & Keterampilan yang dibutuhkan \\
\hline & 0 & $\begin{array}{l}\text { Tidak perlu lagi keterampilan baru bagi staf, manajemen, keduanya telah } \\
\text { berpengalaman }\end{array}$ \\
\hline & 1 & Dibutuhkan beberapa keterampilan baru bagi staf, tidak untuk manajemen \\
\hline
\end{tabular}




\begin{tabular}{|c|c|c|}
\hline & 2 & Dibutuhkan beberapa keterampilan baru bagi staf dan manajemen \\
\hline & 3 & Dibutuhkan beberapa keterampilan bagi staf, terlebih bagi manajemen \\
\hline & 4 & Keterampilan baru banyak dibutuhkan bagi staf, beberapa bagi manajemen \\
\hline & 5 & Keterampilan baru banyak dibutuhkan bagi staf dan manajemen \\
\hline \multirow[t]{7}{*}{5} & B & Ketergantungan perangkat keras \\
\hline & 0 & Perangkat keras digunakan untuk aplikasi yang sejenis \\
\hline & 1 & Perangkat keras digunakan, tetapi untuk aplikasi yang berbeda \\
\hline & 2 & Perangkat kerasnya ada dan sudah diuji, tetapi tidak beroperasi \\
\hline & 3 & Perangkat kerasnya ada, tetapi belum dimanfaatkan dalam organisasi \\
\hline & 4 & Beberapa fasilitas tidak diuji atau tidak dimanfaatkan \\
\hline & 5 & Persyaratan tidak tersedia dalam konfigurasi sistem informasi saat ini \\
\hline \multirow[t]{7}{*}{0} & $\mathrm{C}$ & Ketergantungan perangkat lunak (selain aplikasi perangkat lunak) \\
\hline & 0 & Perangkat lunak yang standard atau tidak membutuhkan pemograman \\
\hline & 1 & $\begin{array}{l}\text { Perangkat lunak yang standard tetapi membutuhkan pemograman yang } \\
\text { komples }\end{array}$ \\
\hline & 2 & $\begin{array}{l}\text { Dibutuhkan beberapa interface antar perangkat lunak, dan mungkin } \\
\text { membutuhkan pemograman yang kompleks }\end{array}$ \\
\hline & 3 & $\begin{array}{l}\text { Dibutuhkan beberapa fitur baru pada perangkat lunak, dan mungkin } \\
\text { diperlukan juga interface yang kompleks antar perangkat lunak }\end{array}$ \\
\hline & 4 & $\begin{array}{l}\text { Fitur yang dibutuhkan tidak tersedia sekarang, dan dibutuhkan perbaikan } \\
\text { dengan level kulaitas yang cukup tinggi }\end{array}$ \\
\hline & 5 & $\begin{array}{l}\text { Dibutuhkan perbaikan dengan level kualitas yang sangat tinggi dan } \\
\text { signifikan }\end{array}$ \\
\hline \multirow[t]{7}{*}{5} & $\mathrm{D}$ & Aplikasi perangkat lunak (program) \\
\hline & 0 & Program yang ada hanya membutuhkan modifikasi sedikit \\
\hline & 1 & $\begin{array}{l}\text { Program dapa dibeli dengan sedikit modifikasi, atau program telah tersedia } \\
\text { dan membutuhkan modifikasi agak banyak, atau mengembangkan program } \\
\text { sendiri dengan kompleksitas seminimal mungkin }\end{array}$ \\
\hline & 2 & $\begin{array}{l}\text { Program dapa dibeli dengan modifikasi yang agak banyak, atau program } \\
\text { telah tersedia dan membutuhkan banyak modifikasi, atau mengembangkan } \\
\text { program sendiri dengan rancangan yang tidak terlalu rumit, namun dengan } \\
\text { pemograman yang cukup kompleks }\end{array}$ \\
\hline & 3 & $\begin{array}{l}\text { Program dapat dibeli tetapi sangat kompleks, atau program dikembangkan } \\
\text { sendiri dengan tingkat kesulitan sedang }\end{array}$ \\
\hline & 4 & $\begin{array}{l}\text { Tidak memiliki program dan juga tidak tersedia di pasar, membutuhkan } \\
\text { program yang kompleks dengan tingkat kesulitan sedang }\end{array}$ \\
\hline & 5 & $\begin{array}{l}\text { Tidak memiliki program dan juga tidak tersedia di pasar, membutuhkan } \\
\text { program yang sangat kompleks dan tingkat kesulitan yang tinggi, mungkin } \\
\text { dilakukan outsourcing }\end{array}$ \\
\hline
\end{tabular}

Setelah seluruh hasil perhitungan sudah dikumpulkan, maka seluruh nilai tersebut dimasukkan ke dalam Information Economics Scorecard. Nilai-nilai tersebut dikalikan dengan nilai bobot yang sudah ditentukan sebelumnya. 
Computatio: Journal of Computer Science and Information Systems, volume 1, no 2, Oktober 2017

Tabel 5.Information Economics Scorecard

\begin{tabular}{|c|c|c|c|c|c|c|c|c|c|c|}
\hline \multirow{4}{*}{$\begin{array}{l}\text { Business Domain } \\
\text { Technology Domain }\end{array}$} & $\mathrm{ROI}$ & SM & $\mathrm{CA}$ & MI & $\mathrm{CR}$ & OR & SA & DU & IR & TU \\
\hline & + & + & + & + & + & - & + & - & - & - \\
\hline & 1 & 1 & 0 & 5 & 4 & 0.5 & & & & \\
\hline & & & & & & & 2 & 1 & 2 & 3 \\
\hline Weight Distribution & 1 & 1 & 1 & 1 & 1 & 1 & 1 & 1 & 1 & 1 \\
\hline Summary & 1 & 1 & 0 & 5 & 4 & -0.5 & 2 & -1 & -2 & -3 \\
\hline $\begin{array}{l}\text { Total Value } \\
\text { Total Risk }\end{array}$ & $\begin{array}{c}13 \\
-6.5\end{array}$ & & & & & & & & & \\
\hline
\end{tabular}

Dari hasil perhitungan, didapatkan Total Value aplikasi Fixed Asset Management System sebesar 13 dari Maximum Value 30, sedangkan Total Risk sebesar -6,5 dari Maximum Risk -20.

Hasil evaluasi berdasarkan IE yang dapat digunakan untuk melakukan enhancement berikutnya dititik-beratkan pada peningkatan value dan pengurangan resiko yang diderita, berikut adalah rinciannya:

1. Dilihat dari Competitive Advantage, maka aplikasi enhancement berikutnya dapat dititikberatkan pada keterhubungan aplikasi dengan aplikasi stakeholder universitas. Aplikasi dapat melakukan komunikasi dengan tujuan mempercepat proses bisnis universitas seperti otomatisasi permintaan stok yang sudah menipis.

2. Dilihat dari Competitive Response, maka aplikasi enhancement berikutnya tidak dapat tertunda implementasinya, mengingat bahwa value untuk aplikasi enhancement berikutnya sudah lebih tinggi, yaitu mencakup lebih banyak keterhubungan komunikasi dengan aplikasi lain seperti aplikasi Accounting.

3. Dilihat dari Project Organizational Risk, maka rencana dan persiapan implementasi seperti Contigency Plan, SOP, User Trainning, dan lainnya.

4. Dilihat dari IS Architecture, maka sebelum melakukan enhancement universitas perlu untuk merancang IT Blueprint. Hal ini diperlukan untuk dapat memetakan secara jelas posisi dan alur komunikasi aplikasi Fixed Asset Management System dengan rencana pengembangan aplikasi lainnya. Selain hal tersebut, IT Blueprint dibutuhkan untuk melakukan prioritas terhadap proyek-proyek IT yang akan direalisasi.

5. Dilihat dari Definitional Uncertainty, maka sebelum aplikasi enhancement dilakukan, pihak universitas dan vendor bersama-sama harus menentukan spesifikasi yang dibutuhkan secara lengkap dan jelas. Jika memungkinkan sebuah SOP baru harus dibentuk untuk membantu proses pembangunan aplikasi.

Proses penilaian terhadap Critical Success Factor untuk aplikasi Fixed Asset Management System universitas Confidential dilakukan secara wawancara dengan pihak internal auditor yang menjadi person-in-charge untuk pembangunan dan penerapan aplikasi ini. Wawancara dilakukan dengan face-to-face, dan wawancara ini bertujuan untuk mengambil faktor-faktor yang menjadi faktor kesuksesan aplikasi ini terhadap proses bisnis yang terjadi di universitas. Setelah faktor-faktor tersebut diambil dan disimpulkan, maka faktor-faktor tersebut dibandingkan dengan keadaan yang sudah dicapai dengan penerapan aplikasi ini. 
Tabel 6.Critical Success Factor Scorecard

\begin{tabular}{|c|c|c|c|}
\hline Critical Success Factor & Tolak Ukur & Target & Pencapaian \\
\hline $\begin{array}{l}\text { Seluruh inventori yang berada di } \\
\text { dalam Universitas harus dapat } \\
\text { diketahui dan dikontrol oleh pihak } \\
\text { manajemen. }\end{array}$ & $\begin{array}{l}\text { Persentase dari jumlah } \\
\text { property yang dimiliki oleh } \\
\text { universitas confidential }\end{array}$ & $100 \%$ & $100 \%$ \\
\hline $\begin{array}{l}\text { Operasi sehari-hari yang } \\
\text { melibatkan inventori universitas } \\
\text { harus dapat dicatat dengan mudah. }\end{array}$ & $\begin{array}{l}\text { Persentase dari jumlah } \\
\text { property yang menggunakan } \\
\text { barcode }\end{array}$ & $100 \%$ & $100 \%$ \\
\hline $\begin{array}{l}\text { Seluruh inventori harus memiliki } \\
\text { riwayat perpindahan lokasi dan } \\
\text { status sehingga seluruh aktivitas } \\
\text { yang pernah terjadi dapat } \\
\text { dipertanggungjawabkan. }\end{array}$ & 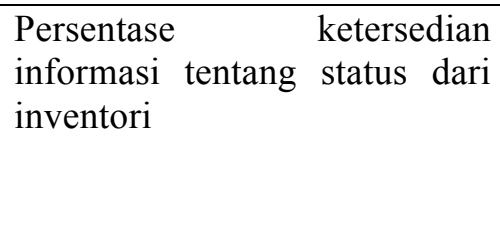 & $100 \%$ & $100 \%$ \\
\hline $\begin{array}{l}\text { Manajemen harus dapat } \\
\text { mengetahui dengan cepat keadaan } \\
\text { inventori yang berada di seluruh } \\
\text { lokasi universitas. }\end{array}$ & $\begin{array}{lrr}\text { Persentase dimana informasi } \\
\text { dapat diberikan } & \text { ke } \\
\text { management dalam } & \text { waktu } \\
\text { dibawah } 10 \text { detik } & \end{array}$ & $100 \%$ & $100 \%$ \\
\hline $\begin{array}{l}\text { Manajemen mempersiapkan segala } \\
\text { sesuatunya untuk memenuhi } \\
\text { standarisasi ISO 9001:2008. }\end{array}$ & $\begin{array}{llr}\text { Persentase } & \text { availaibility dari } \\
\text { aplikasi } & \text { Fixed } & \text { Asset, } \\
\text { accounting and HRD untuk } \\
\text { mendapatkan informasi }\end{array}$ & $100 \%$ & $30 \%$ \\
\hline
\end{tabular}

\section{KESIMPULAN}

Setelah proses evaluasi terhadap aplikasi Fixed Asset Management System menggunakan metode Return On Investment, Information Economics, dan Critical Success Factor selesai dilakukan, maka didapat beberapa kesimpulan sebagai berikut:

1. Hasil penilaian Return On Investment yang bernilai $29.09 \%$ setelah implementasi aplikasi Fixed Asset Management System. Nilai pertambahan didapat dari dampak ekonomi langsung yang melibatkan penghilangan biaya.

2. Nilai tersebut adalah nilai yang didapat dengan menghitung angka yang pasti didapatkan. Banyak terdapat asset yang hilang dari kepemilikan dikarenakan beberapa hal. Dikarenakan data pembelian tidak dapat diperoleh karena informasi yang tidak disimpan, maka perhitungan ROI tidak sepenuhnya menggambarkan keadaan ROI yang sebenarnya.

3. Hasil penilaian Information Economics dimana didapatkan total value yang dicapai aplikasi Fixed Asset Management System sebesar 13 dari maximum value 30 yang dapat diperoleh. Hasil ini menandakan bahwa aplikasi Fixed-Asset Management yang ada di universitas Confidential masih dapat ditingkatkan dari sisi value-nya. Perbaikan dilihat dari metode Return On Investment, Information Economics, dan Critical Success Factor.

4. Hasil penilaian Information Economics dimana didapatkan total risk yang dicapai aplikasi Fixed Asset Management System sebesar -13 dari maximum risk -20 yang dapat diderita. Hal ini menandakan bahwa resiko aplikasi ini masih cukup besar, yaitu lebih dari 50\% dari yang dapat diterima.

5. Didapatkan bahwa pertimbangan terbesar bagi manajemen adalah pada bagian Strategic Match, Management Information, dan IS Infrastructure. Hal ini menunjukkan bahwa aplikasi Fixed Asset Management System adalah penting bagi sektor strategis, informasi, dan infrastruktur organisasi. 
Computatio: Journal of Computer Science and Information Systems, volume 1, no 2, Oktober 2017

6. Hasil pengambilan dan penilaian terhadap Critical Success Factor menunjukkan bahwa terdapat 5 point kritis yang harus dipenuhi dalam pencapaian tujuan asset management di Universitas. Dari hasil analisis, Aplikasi Fixed Asset Management System berkontribusi terhadap 4 dari 5 faktor tersebut. Hal ini menunjukkan bahwa aplikasi Fixed Asset Management System memiliki kontribusi yang besar bagi manajemen dalam memenuhi objective asset management di universitas.

\section{DAFTAR PUSTAKA}

[1] Andersen, Jan L. (2001).A Framework for Selecting an IT Evaluation Method. Danmarks Tekniske Universitet.

[2] Parker, M.M., Benson, R.J., Trainor, H.E. (1988).Information Economics: Linking Business Performance to Information Technology. Prentice Hall.

[3] Prakken, B. (2000). Information, organization and information systems design: an integrated approach to information problems.Springer.

[4] Rockart, John F. (1979). Chief executives define their own data needs. Harvard Business Review. 